\title{
Anti-ribosomal P protein antibodies detected by immunoblotting in patients with connective tissue diseases: their specificity for SLE and association with IgG anticardiolipin antibodies
}

\author{
A Ghirardello, A Doria, S Zampieri, R Gerli, E Rapizzi, P F Gambari
}

\begin{abstract}
Objective-To assess the prevalence and clinical and serological associations of anti-ribosomal $P$ protein antibodies (anti-P antibodies) in patients with connective tissue diseases (CTDs) and investigate the immunobiological nature of autoantibody clustering in which anti-P antibodies play a part.

Methods-IgG anti-P antibodies in the sera of 267 patients with CTDs and 31 healthy subjects were analysed by immunoblotting performed on cytoplasmic extract of Raji cells. 60 patients with systemic lupus erythematosus (SLE), 32 systemic sclerosis, 46 primary Sjögren's syndrome, 16 poly/dermatomyositis, 11 rheumatoid arthritis, 8 undifferentiated CTD, 72 overlap CTD, and 22 primary antiphospholipid syndrome were studied. Anti-P antibodies were affinity purified by elution from nitrocellulose bound antigen and tested by ELISA for their binding activity to cardiolipin.
\end{abstract}

Results-Anti-P antibodies were detected in $16(6 \%)$ patients and in none of the controls: $12 / 60$ SLE $(20 \%)$ and $4 / 80$ undifferentiated/overlap patients with CTD (5\%). A close association of IgG antibodies with $P$ proteins and with cardiolipin was seen in lupus sera $(p=0.0009$, odds ratio 18.33). Anti-P antibodies from 9 of 12 anti-P lupus serum samples could be affinity purified and none of the affinity purified fractions cross reacted with ELISA plate coated cardiolipin.

Conclusions-Anti-P immunoreactivity is a specific marker of SLE and lupus-like disease and its detection is recommended as a powerful diagnostic tool. Anti-P antibodies are strongly clustered with IgG anticardiolipin antibodies in lupus sera, even if they are independently elicited. This suggests that their cognate autoantigens play a part in a common pathogenetic pathway in SLE.

(Ann Rheum Dis 2000;59:975-981)

A characteristic feature of patients with connective tissue diseases (CTDs) is detection of high levels of autoantibodies to intracellular "self" antigens in the serum. Together with antibodies specific for nuclear constituents, immunoreactivities to cytoplasmic components are also identified. Among them, antiribosomal antibodies are biologically well char- acterised, but a great deal of research is still devoted to their clinical and pathogenetic significance. ${ }^{1}$ They may recognise ribosomal $\mathrm{RNA}^{23}$ or protein epitopes within eukaryotic ribosome subunits. Three alanine-rich phosphoproteins ("P" proteins), P0, P1, and P2, with an apparent molecular weight of 38,19 , and $17 \mathrm{kDa}$ respectively, are the major targets of antibodies to ribosomal proteins ${ }^{2}{ }^{4}$; rarely, proteins other than the $\mathrm{P}$ proteins are also recognised as autoantigens. ${ }^{56}$

The autoimmune response against ribosomes has recently received increasing attention owing to the characterisation, sequencing, and synthesis of antigenic determinants and subsequent improvement in proper detection methods. Anti-P immunodominant epitope is a single sequential epitope contained within a 22 amino acid carboxy terminal peptide shared by the three P proteins, ${ }^{7}$ though evidence of antibodies recognising a conformational determinant(s) has also been obtained.

Anti-P antibodies are predominantly found in the serum of patients with systemic lupus erythematosus (SLE), and their association with neuropsychiatric, hepatic, and renal disease has long been controversial and is still being investigated. ${ }^{189}$

Detection of anti-P antibodies is not so easily approached: discordant data and laboratory shortcomings are common. Nowadays, immunoblotting and enzyme linked immunosorbent assay (ELISA) techniques have the highest sensitivity and specificity. Western blotting on purified ribosomes is considered the gold standard ${ }^{10}{ }^{11}$ and agrees well with quantitative tests, such as radioimmunoassay and ELISA, ${ }^{11-13}$ being, therefore, the most commonly used confirmatory test.

Our study was undertaken to evaluate the sensitivity and specificity of anti-P antibodies detected by immunoblotting for the classification of individual CTDs in the serum samples of a large cohort of patients and to investigate the possible associations of anti-P antibodies with other serum autoantibodies. Blot-affinity purification of circulating anti-P antibodies was used to determine the immunological nature of serological clustering.

\section{Methods}

Serum samples were obtained from 267 unselected white patients affected with different CTDs and from 31 matched healthy blood donors as controls. Sixty patients were classified as SLE according to the American College of 
Rheumatology revised criteria, ${ }^{14} 32$ diffuse or limited scleroderma, ${ }^{15} 46$ primary Sjögren's syndrome, ${ }^{16} 16$ polymyositis or dermatomyositis, ${ }^{17} 11$ rheumatoid arthritis, ${ }^{18}$ eight undifferentiated CTD on the basis of insufficient criteria for classification as a defined CTD, ${ }^{19}$ and 72 overlap CTD according to specific clinical manifestations of more than one CTD. Additionally, serum samples from 22 patients with primary antiphospholipid syndrome were tested. $^{20}$

At the time of blood sampling, specific drug treatment was registered for all patients. In SLE we also evaluated disease activity according to the doctor's global assessment. ${ }^{21}$ All patients with SLE were evaluated by one rheumatologist (AD). In 35 cases the disease was active.

IgG antibodies to ribosomal $\mathrm{P}$ proteins and to other cytoplasmic antigens were detected by western blotting as previously described. ${ }^{22}$ Briefly, nuclear and cytoplasmic extracts were prepared from Raji cells cultured in RPMI 1640 containing $10 \%$ heat inactivated fetal calf serum (Gibco UK, Ltd), penicillin, and streptomycin, according to McHugh et al. ${ }^{23}$ All extraction buffers contained $1 \mathrm{mM}$ phenylmethylsulphonylfluoride (Sigma Chemical Co, St Louis, MO) and $10 \mu \mathrm{g} / \mathrm{ml}$ leupeptin. After two washes in cold phosphate buffered saline (PBS; $10 \mathrm{mM}$ sodium phosphate, $150 \mathrm{mM} \mathrm{NaCl}, \mathrm{pH} 7.4$ ), cells were resuspended at a concentration of $100 \times 10^{6}$ cells $/ \mathrm{ml}$ in cold hypotonic phosphate buffer $(10$ $\mathrm{mM}$ sodium phosphate, $10 \mathrm{mM} \mathrm{NaCl}, \mathrm{pH} 7.4$ ) containing $0.5 \%$ Triton $\mathrm{X}-100$ for $30-40$ minutes on ice. After about 20-30 minutes cells were passed through a $0.2 \mathrm{~mm}$ diameter needle to facilitate breaking of cell membranes. Subsequently, the nuclei were pelleted (5000 rpm for 15 minutes, $4^{\circ} \mathrm{C}$ ) and the supernatant was retained as the cytoplasmic fraction. The nuclei were resuspended at a concentration of $100 \times$ $10^{6}$ nuclei $/ \mathrm{ml}$ in cold hypertonic phosphate buffer (10 mM sodium phosphate, $350 \mathrm{mM}$ $\mathrm{NaCl}, \mathrm{pH} 7.4$ ), agitated for 10 minutes, and then sonicated at least five times for 10-20 seconds. Cell debris was then removed by centrifugation (5000 rpm for 15 minutes, $4^{\circ} \mathrm{C}$ ) and the supernatant was retained as the nuclear fraction.

The cytoplasmic extract was used as the source of ribosomal proteins and underwent $15 \%$ sodium dodecyl sulphate-polyacrylamide gel electrophoresis (SDS-PAGE) under reducing conditions (Hoefer Scientific Instruments, Amersham Pharmacia Biotech, Uppsala, Sweden) according to the method described by Laemmli $\left(2 \times 10^{6}\right.$ cell equivalents $/ \mathrm{cm}$ gel width). ${ }^{24}$ After separation, proteins were electrotransferred from the gel to a nitrocellulose sheet overnight with a constant current (Hoefer Scientific Instruments), according to the method of Towbin et al. ${ }^{25}$ Strips were then cut and saturated with $2 \%$ casein in Trisbuffered saline $(10 \mathrm{mM}$ Tris $\mathrm{HCl}, 500 \mathrm{mM}$ $\mathrm{NaCl}, \mathrm{pH} \mathrm{7.5)}$, for at least one hour at room temperature. After blocking, they were probed (three hours, room temperature) with patients' serum samples diluted $1 / 100$ in Tris buffer/ $0.2 \%$ casein, washed six times, and then incubated (one hour, room temperature) with horseradish peroxidase conjugated goat anti- human IgG antibodies (Sigma) diluted 1/1000 with PBS $/ 0.2 \%$ casein. After three washes, specific antibody binding was detected by adding 4-chloro-1-naphthol as the substrate.

To analyse cross reactivities, antibodies against $\mathrm{P} 0, \mathrm{P} 1$, and $\mathrm{P} 2$ proteins were affinity purified from the serum samples of lupus patients by elution from nitrocellulose bound antigen according to the method of Olmsted ${ }^{26}$ with some modifications. Cytoplasmic extract of Raji cells was electrophoretically resolved and transferred onto nitrocellulose paper. To identify the position of the P proteins, vertical strips from either side of the blot were probed with anti-P prototype serum and used for orientation. Horizontal strips (approximately $0.2 \times 6 \mathrm{~cm}$ ) were cut corresponding to the region of $\mathrm{P}$ proteins and to a negative control region and first incubated with blocking solution (one hour, room temperature) and then with patient serum diluted $1: 10$ in $0.2 \%$ casein/Tris buffered saline (two hours, room temperature). After extensive washing with PBS, strips were cut into small pieces and bound antibodies were eluted with $0.2 \mathrm{M}$ glycine/ $\mathrm{HCl} \mathrm{pH} 2.8$ (4 minutes' incubation, $4^{\circ} \mathrm{C}$ ), immediately neutralised with $1 \mathrm{M}$ $\mathrm{NaOH}$, and equilibrated with PBS. Elution samples were concentrated by ultrafiltration using Centricon 50 tubes (Millipore, Bedford, $\mathrm{MA}$ ) and subsequently analysed by immunoblotting for anti-P reactivity (at a 1:10 dilution) and by ELISA for IgG anticardiolipin antibody (aCL) positivity (undiluted). In an effort to characterise anti-P specificity of the affinity purified preparations, a densitometric analysis of paired cytoplasmic blots of the anti-P positive sera and the respective affinity purified fractions was performed, blot samples were scanned by a GS-300 transmittance-reflectance scanning densitometer (Hoefer), and corresponding values were converted into optical density arbitrary units by a GS-370 computed data system. ${ }^{27}$ Additionally, both sera and respective purified fractions were tested by indirect immunofluorescence on Hep-2 cells.

Anti-small nuclear ribonucleoproteins (RNPs) and other anti-extractable nuclear antigen antibodies were detected by counterimmunoelectrophoresis ${ }^{28}$ and confirmed by immunoblotting on nuclear and cytoplasmic Raji cells extracts, resolved on $12.5 \%$ and $15 \%$ SDS-PAGE respectively, by the methods mentioned above. ${ }^{22} 27$ Antinuclear antibodies, anticentromere and anti-double stranded (ds) DNA antibodies were detected by indirect immunofluorescence on Hep-2 cells and Crithidia luciliae, respectively. Reference sera were provided from the Centres for Disease Control (Atlanta, USA). The anti-P prototype serum was specific only for the $\mathrm{P}$ protein autoantigens.

Antiphospholipid antibodies (aPL) were detected as reported elsewhere. ${ }^{29}$ Serum IgG and IgM aCL were measured by ELISA according to the method of Harris. ${ }^{30}$ Results were expressed as G antiphospholipid (GPL) and $M$ antiphospholipid (MPL) units obtained from the standard curve built with Harris' reference sera. The mean value + 3SD of 100 healthy subjects (11.6 GPL and 7.5 MPL) was considered 
as the cut off point for both $\operatorname{IgG}$ and $\operatorname{IgM}$ aCL levels. Lupus anticoagulant (LA) was determined by the diluted Russell viper venom time according to the method of Thiagarajan et al. ${ }^{31}$

Statistical analysis was performed by two sided Fisher's exact test. Sensitivity for SLE = (number of anti-P positive patients with SLE/ total patients with SLE) $\times 100$. Specificity for SLE (with respect to healthy subjects) = (number of anti-P negative healthy subjects/ total healthy subjects $) \times 100$; specificity for SLE (with respect to defined CTDs other than SLE or undifferentiated/overlap CTDs) = (number of anti-P negative patients with CTD/total patients with CTD) $\times 100$. Linear regression analysis was used to evaluate the correlation between the IgG anti-P concentrations in the serum samples and the affinity purified preparations, expressed as optical density arbitrary units.

\section{Results}

Sixteen of $267(6 \%)$ patients with CTDs were positive for anti-P antibodies by immunoblotting - 12/60 with SLE (20\%) and $4 / 80$ with undifferentiated/overlap CTD (5\%). Figure 1 shows representative immunoblots of serum samples from healthy subjects on Raji cytoplasmic extract and fig 2 shows typical immunoblot profiles of anti-P positive SLE sera. Anti-P antibodies were significantly more common in patients with SLE than in healthy subjects $(p=0.0068)$ or in patients with other CTDs $(p<0.00001)$.

Figure 3 shows the sensitivity and specificity of anti-P antibodies detected by immunoblotting for the diagnosis of SLE in our patient group. Patients with primary Sjögren's syndrome, systemic sclerosis, poly/dermatomyositis, primary antiphospholipid syndrome, rheumatoid arthritis, and matched healthy subjects did not show any serum reactivity towards $P$ proteins.

SLE activity did not correlate with anti-P positivity assessed by the doctor's global assessment. At the time of blood sampling, the incidence of prominent clinical features in patients with SLE with and without anti-P antibodies was similar. At the time of the study, 16 patients with SLE were receiving no treatment, 20 patients were taking prednisone at a daily dose $\leq$ of $10 \mathrm{mg}$ and 24 patients at daily doses of $>10 \mathrm{mg}$. Nine patients were also taking immunosuppressants. To exclude the possibility that immunosuppressive treatment might have given false negative results, we collected and tested serum samples from five of the nine patients with SLE when they were not receiving immunosuppressive treatment. The results were the same, both with and without immunosuppressive treatment.

Table 1 reports the association of anti-P antibodies with other autoantibodies in patients with CTD. Anti-P antibodies were not

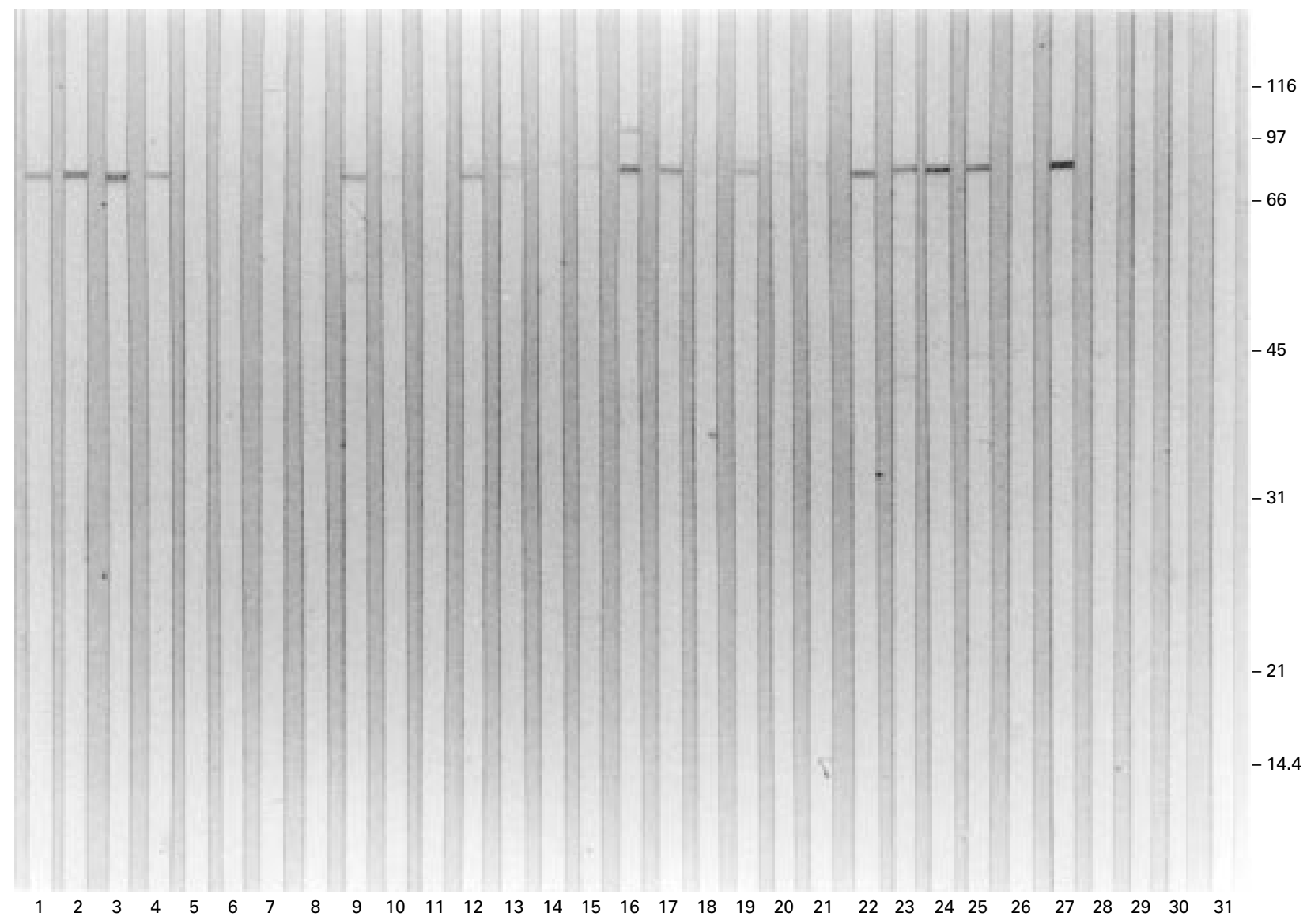

Figure 1 Immunoblot analysis of serum samples from healthy donors on cytoplasmic extract of Raji cells resolved on $15 \%$ SDS-PAGE. Molecular weight markers are indicated in kilodaltons on the right. 


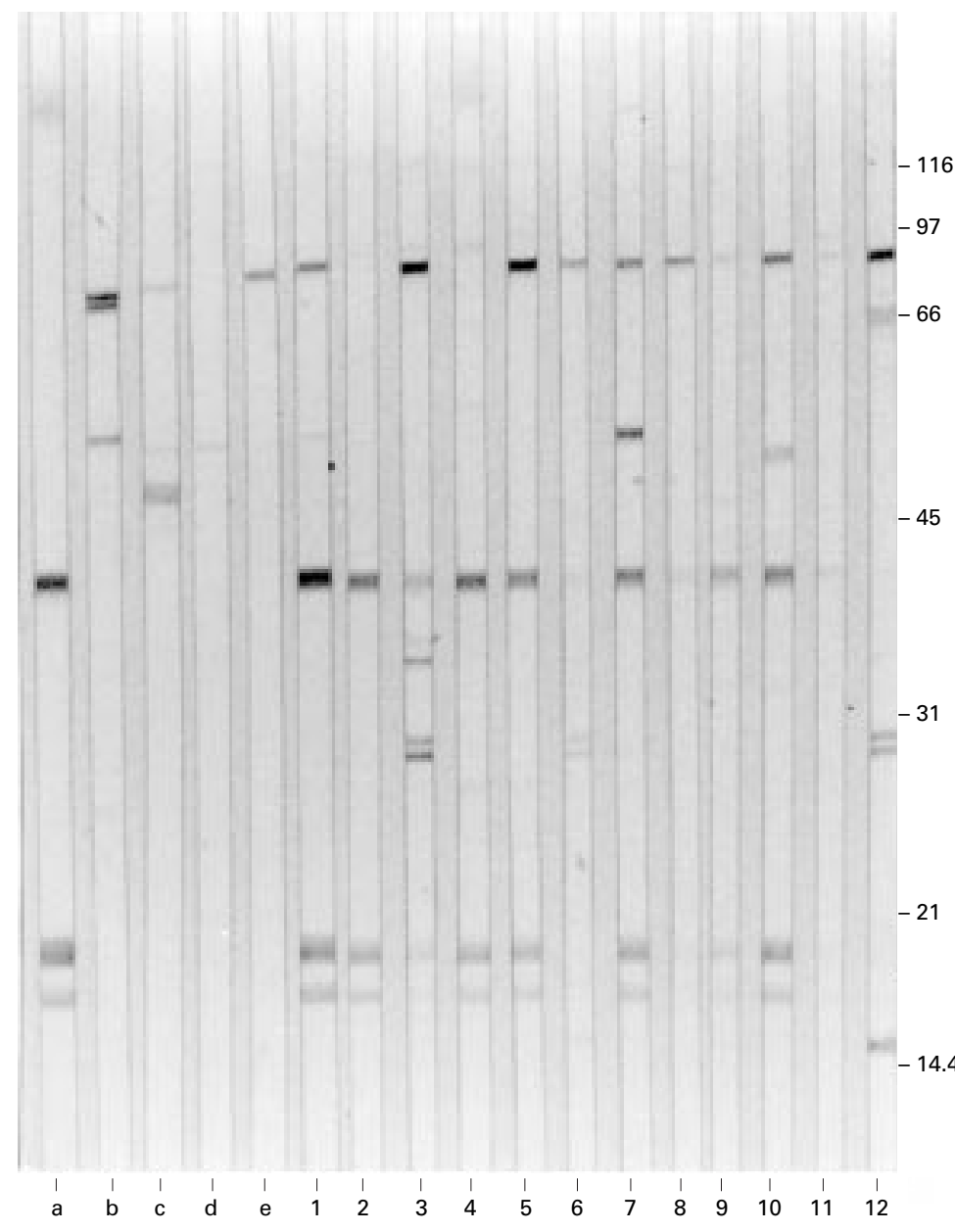

Figure 2 Analysis of anti-P positive SLE sera (lanes 1-12) on a cytoplasmic blot. Immunoblot was interpreted as positive with concomitant lines corresponding to $38 \mathrm{kDa}, 19$ $k D a$, and $17 \mathrm{kDa}$ bands. Control sera: (a) anti-P prototype serum; (b) anti-mitochondrial protein serum; (c) anti-La/SSB + anti-Ro/SSA 52 kDa serum; (d) anti-fo-1 serum; (e) control serum from a healthy donor showing the background band typically present in Raji cell extracts. Molecular weight markers are indicated in kilodaltons on the right.

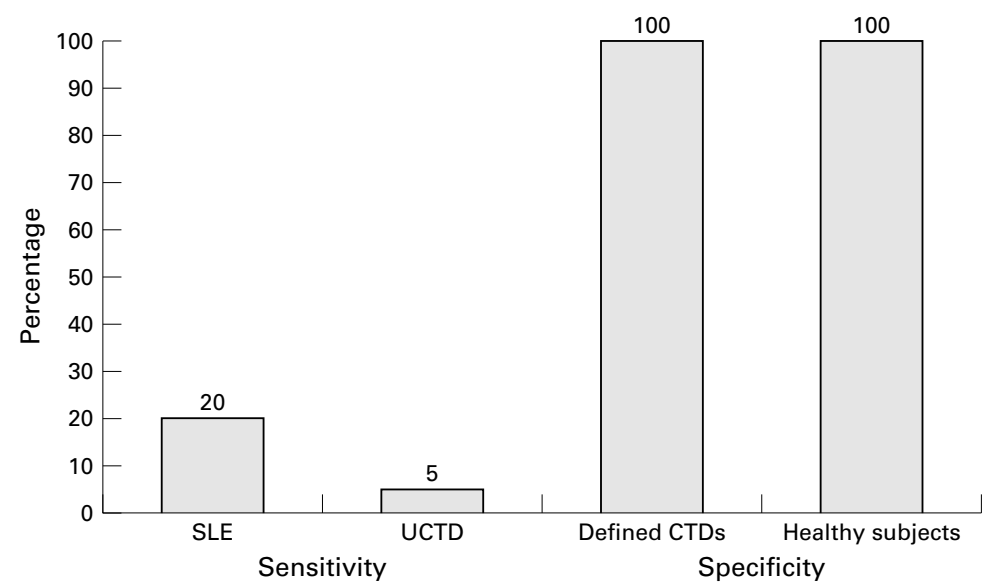

Figure 3 Anti-P antibody detected by immunoblotting: sensitivity for systemic lupus erythematosus (SLE) and undifferentiated/overlap connective tissue diseases (UCTD) diagnosis and its specificity in healthy subjects and CTDs other than SLE or UCTD.

associated with any antinuclear antibodies, neither anti-dsDNA nor anti-Sm antibodies, as confirmed by screening on nuclear blot. Antiphospholipid antibodies were detected in the serum samples of $33 / 60(55 \%)$ patients with SLE (IgG aCL in 24, IgM aCL in four, both IgG and IgM in five, LA in four patients always associated with IgG aCL positivity), in $17 / 37(46 \%)$ patients with UCTD, and in 20/22 (91\%) with antiphospholipid syndrome (APS). Five of 60 patients with SLE also fulfilled the diagnostic criteria for APS, ${ }^{20}$ having had one or more episodes of venous thrombosis and all being aCL positive. Two of the 14 female patients with SLE who became pregnant after disease onset, had a stillbirth; both were aPL negative during pregnany complications and at the time of the study. We found no association of aCL with thrombosis or recurrent fetal loss in our patients. Anti-P antibodies were significantly associated with IgG aCL ( $p=0.0009$, odds ratio $18.33,95 \%$ confidence interval 2.180 to 154.2 ) but not with IgM aCL or LA positivity in patients with SLE (fig 4). Interestingly, none of the anti-P positive lupus patients had antiphospholipid syndrome and none of the serum samples from patients with a diagnosis of primary antiphospholipid syndrome contained anti-P antibodies. In $3 / 60(5 \%)$ lupus sera, anti-P reactivity was the only specific antibody detected; all these sera were also positive for IgG aCL.

To determine whether the close association of IgG antibodies with P proteins and with cardiolipin in lupus sera was due to cross reactivity, anti-P antibodies were affinity purified from the anti-P positive lupus sera $(n=12)$. Figure 5 shows an example of affinity purification of anti-P antibody from a patient serum. Purified immunoglobulins from nine of 12 lupus sera retained $\mathrm{P}$ protein binding activity after acid treatment, and blot densitometric analysis showed that IgG anti-P concentrations in the

Table 1 Frequency of autoantibodies in patients with systemic lupus erythematosus (SLE), undifferentiated/ overlap CTD (UCTD), and primary antiphospholipid syndrome (APS) and their association with anti-P antibodies. (All values are expressed as number (\%))

\begin{tabular}{|c|c|c|c|}
\hline & $\begin{array}{l}\text { Total } \\
\text { patients }\end{array}$ & $\begin{array}{l}\text { Anti-P } \\
\text { positive } \\
\text { patients }\end{array}$ & $\begin{array}{l}\text { Anti-P } \\
\text { negative } \\
\text { patients }\end{array}$ \\
\hline SLE $(n=60)$ & & $(n=12)$ & $(n=48)$ \\
\hline Anti-dsDNA & $38(63)$ & $8(67)$ & $30(63)$ \\
\hline Anti-Sm & $17(28)$ & $2(17)$ & $15(31)$ \\
\hline Anti-nRNP & $23(38)$ & $2(17)$ & $21(44)$ \\
\hline Anti-Ro/SSA & $20(33)$ & $2(17)$ & $18(38)$ \\
\hline Anti-La/SSB & $5(8)$ & $1(8)$ & $4(8)$ \\
\hline IgG aCL & $29(48)$ & $11(92) \dagger$ & $18(38)$ \\
\hline $\mathrm{IgM}$ aCL & $9(15)$ & $3(25)$ & $6(13)$ \\
\hline LA & $4(7)$ & $2(17)$ & $2(4)$ \\
\hline $\begin{array}{l}\text { Overlap/UCTD }{ }^{\star} \\
(\mathrm{n}=80)\end{array}$ & & $(n=4)$ & $(n=76)$ \\
\hline Anti-dsDNA & $13(16)$ & 0 & $13(17)$ \\
\hline Anti-Sm & $9(11)$ & $1(25)$ & $8(11)$ \\
\hline Anti-nRNP & $50(63)$ & $2(50)$ & $48(63)$ \\
\hline Anti-Ro/SSA & $22(28)$ & $2(50)$ & $20(26)$ \\
\hline Anti-La/SSB & $3(4)$ & 0 & $3(4)$ \\
\hline Anti-Scl70 & $6(8)$ & 0 & $6(8)$ \\
\hline Anti-Jo-1 & $2(3)$ & 0 & $2(3)$ \\
\hline Anticentromere & $4(5)$ & $1(25)$ & $3(4)$ \\
\hline IgG aCL & $17(46)$ & $4(100)$ & $13(33)$ \\
\hline IgM aCL & $3(8)$ & 0 & $3(8)$ \\
\hline LA $\ddagger$ & $2(5)$ & 0 & $2(5)$ \\
\hline $\begin{array}{l}\text { Primary APS } \\
(n=22)\end{array}$ & & $(n=0)$ & $(n=22)$ \\
\hline IgG aCL & $19(86)$ & 0.0 & $19(86)$ \\
\hline IgM aCL & $8(36)$ & 0.0 & $8(36)$ \\
\hline LA & $14(64)$ & 0.0 & $14(64)$ \\
\hline
\end{tabular}

*Thirty seven of 80 patients with overlap/UCTD wer concomitantly tested for antiphospholipid antibodies.

† Significant at $\mathrm{p}=0.0009$, odds ratio $18.33,95 \%$ confidence interval 2.180 to 154.2 .

$\ddagger \mathrm{LA}=$ lupus anticoagulant. 


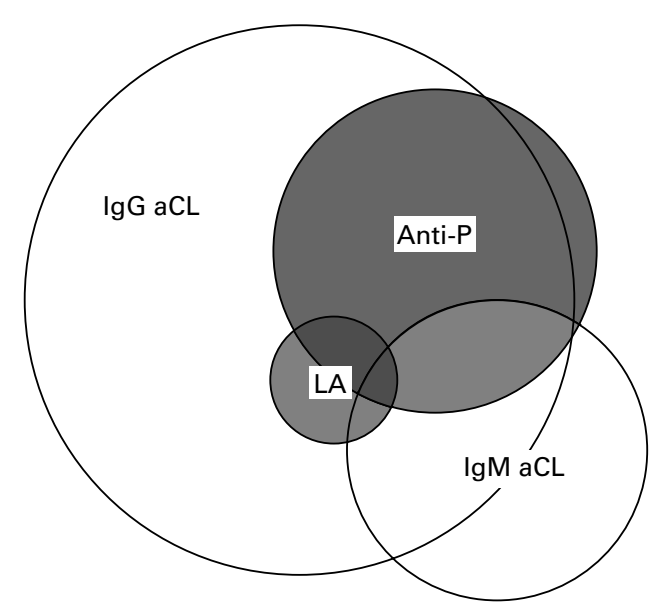

Figure 4 Association of anti-P and antiphospholipid (IgG anticardiolipin antibody (aCL), IgM aCL, lupus anticoagulant $(L A)$ ) responses in patients with systemic lupus erythematosus.

affinity purified preparations matched those in the respective serum samples $(r=0.923$, $\mathrm{p}<0.0001)$; the mean (SD) efficiency of purification was $41.4(9.5 \%)$. Moreover, all the affinity purified fractions had an identical cytoplasmic pattern by indirect immunofluorescence on Hep-2 cells (fine dense granular to homogeneous staining). Affinity purified anti-P fractions, tested on ELISA for IgG aCL activity, did not recognise cardiolipin on ELISA assay, whereas IgG aCL were detected in all serum samples from which anti-P antibodies were purified.

\section{Discussion}

The results of this study demonstrate anti-P antibody detection by immunoblotting on cytoplasmic extract from cultured lymphoid cells. By this technique it is possible to determine simultaneously both precipitating and non-precipitating autoantibodies of many different specificities. ${ }^{32}$ In particular, ribosomal $\mathrm{P}$ proteins can be adequately resolved on one dimensional SDS-PAGE and anti-P reactivity can be easily detected because it produces a peculiar blot pattern by concomitant binding to all three $\mathrm{P}$ proteins. Immunoblotting for the detection of anti-P immunoreactivity is most commonly employed on isolated ribosomal proteins and is considered to be the method with the best sensitivity and specificity. ${ }^{113} 33$ Quantitative ELISAs have also been developed to detect circulating anti-P antibodies. ${ }^{7435}$ Quantification of antibody titres may be important for the serological and clinical follow up of anti-P positive patients. ${ }^{1136}$ Neverthless, ELISA tests still have some limitations and may give conflicting results. Discordant data on the prevalence of anti-P antibody may be due to differences in the nature and purity of the antigens used (synthetic peptides, recombinant fusion proteins, multiple antigen peptides), in the carrier protein to which the peptide may be conjugated, and in the coupling agent used. ${ }^{136-38}$ For such reasons ELISA techniques are still not standardised and immunoblotting is often applied as a confirmatory test.

In this study we were interested in ascertaining the validity of the immunoblotting method

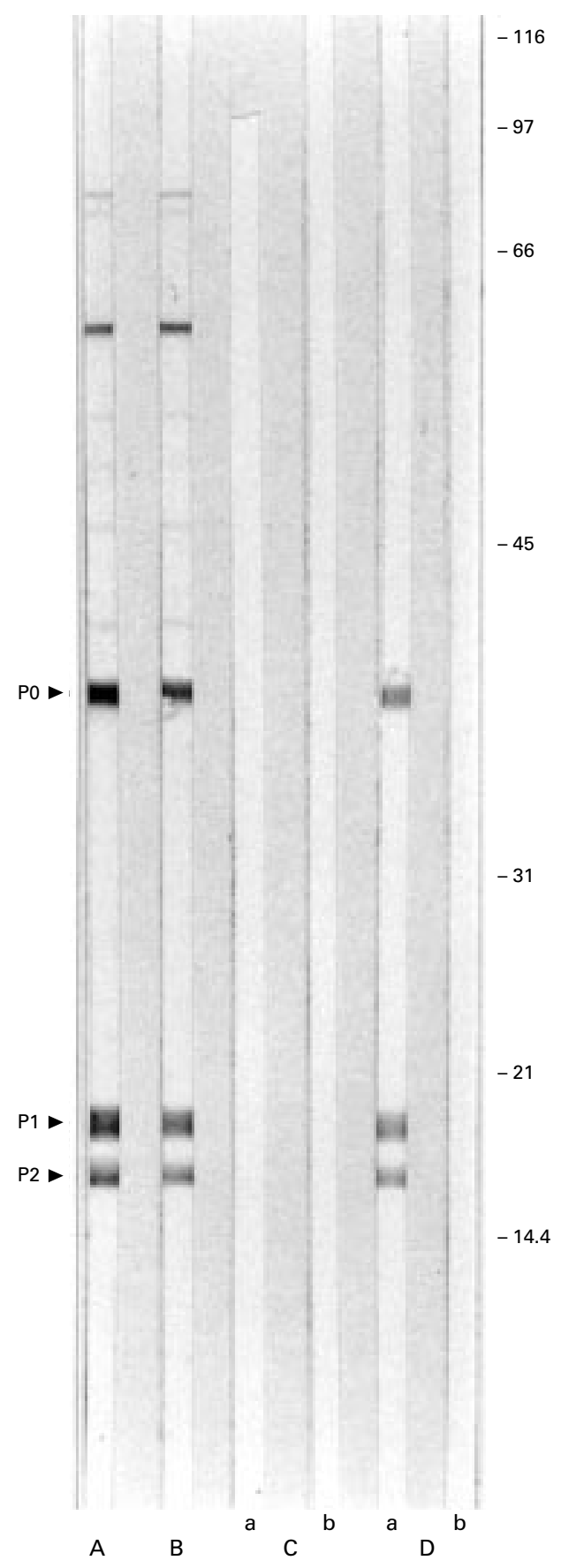

Figure 5 Immunoblot with anti-P serum from a patient with systemic lupus erythematosus and affinity purified fractions (material concentrated or filtrated on Centricon 50 tubes). (A) Anti-P serum after immunoabsorption on a negative control protein region corresponding to $45 \mathrm{kDa}$; (B) the same anti-P serum after immunoabsorption on the regions corresponding to the $P$ proteins of 38,19 , and 17 $\mathrm{kDa} ;(C)$ affinity purified fraction on the negative control protein region ( $a$, concentrated; $b$, filtrated); (D) affinity purified fraction on the P proteins (a, concentrated; $b$, filtrated). Molecular weight markers are indicated in kilodaltons on the right.

when it is applied to total cytoplasmic extract from cultured cells for detection of anti-P antibodies. In our opinion, unsuitability of immunoblotting for routine analysis of anti-P antibodies is largely overcome by its specificity and easy interpretation of anti-P positivity on cytoblots. In an attempt to verify our proposal 
we screened the serum samples from unselected patients with CTDs and healthy subjects for the presence of anti-P antibody by immunoblotting and validated the method's sensitivity and specificity in a clinical context. When our method was used the high specificity of anti-P antibody for the diagnosis of SLE within a large cohort of patients with CTDs was confirmed, and the diagnostic value of anti-P antibody screening in patients with CTDs is strongly recommended. In fact, as previously noted, anti-P antibodies were found in SLE with a sensitivity of $20 \%$. The specificity was $100 \%$ compared with healthy subjects and patients with defined CTD other than SLE or undifferentiated/overlap CTDs, and 95\% compared with patients with undifferentiated/ overlap CTDs. Furthermore, anti-P antibodies did not occur in serum samples of patients with scleroderma, primary Sjögren's syndrome, rheumatoid arthritis, poly/dermatomyositis, and primary APS.

To our knowledge, anti-P antibodies have not previously been investigated in patients with primary APS and the lack of positivity we found is interesting. We confirm that the occasional positivity in patients who do not fulfil the classification criteria of SLE may be predictive of a lupus-like clinical picture. ${ }^{39}{ }^{40}$ Of the four anti-P positive patients classified as undifferentiated/overlap CTD, three had clinical or laboratory characteristics of SLEscleroderma-polymyositis overlap syndrome (two also satisfied Sharp's diagnostic criteria for mixed CTD) and the fourth had major manifestations suggesting polymyositis/ rheumatoid arthritis overlap syndrome. Few case reports of the detection of circulating anti-P antibody in patients with undifferentiated CTD or rheumatoid arthritis have been published. ${ }^{40} 41$

In our cohort anti-P antibodies were strictly associated with the production of IgG antibodies to cardiolipin. Schneebaum et al found a greater frequency of anticardiolipin activity in the anti-P positive lupus patients. ${ }^{42}$ This, however, was not statistically significant, probably because of differences in the sensitivity of the method used for detection of anti-P antibodies, in the isotype/s considered, and in patients' selection criteria. We have shown that such correlation is strong and peculiar to SLE and seems to be confined to a subset of aCL positive patients not at risk from aPL related events. Indeed, in our patients with SLE, thrombotic complications due to aPL were rare. Anti-P antibodies were not associated with any other antinuclear antibodies and were the only antibody specificity in three lupus serum samples, all positive for IgG aCL. In particular, they were not associated either with anti-dsDNA or with anti-Sm antibodies. It is worth noting that we found a relatively high frequency of anti-Sm antibody in lupus patients, probably owing to the short disease duration, the absence of any treatment in some patients, and the increased sensitivity of anti-Sm antibody detection by the addition of Tween 20 in the immunoblotting procedure we used. ${ }^{27}$
To investigate whether such peculiar clustering derives from possible cross reaction of anti-P antibody with cardiolipin, affinity purified antibodies from nitrocellulose bound $\mathrm{P}$ proteins were tested for cardiolipin binding. No cross reactive epitope/s was recognised on ELISA plate coated cardiolipin by affinity purified fractions. These data are in keeping with the lack of anti-P antibody positivity we found in patients with primary APS.

Although we cannot exclude the possibility that additional antibodies specific for conformation(s) of $\mathrm{P}$ protein $\mathrm{s}^{7}$ are cross reactive with cardiolipin, it seems likely that the concurrent autoimmune responses against the two antigens are independently elicited rather than mediated by immunological cross reaction. As no homology seems to exist between P proteins and cardiolipin, their concurrence suggests that the two antibody populations are simultaneously produced and possibly implicated in a common pathogenetic pathway. A mechanism which results in antigenic spreading and autoantibody clustering is dysregulation of apoptosis: surface blebs of apoptotic cells are a major immunogenic particle in SLE. ${ }^{43}$ In ultraviolet induced apoptosis, autoantigens targeted in SLE are clustered in two distinct populations of apoptotic blebs, small blebs containing rough endoplasmic reticulum, ribosomes, and Ro ribonucleoproteins, and large blebs containing nucleosomal DNA, Ro, La, and the small nuclear ribonucleoproteins. ${ }^{43}$ Thus ribosomal and other cytoplasmic autoantigens seem to cluster independently from the nuclear ones. In this context, the significance of the associated immune response against phospholipids was recently investigated. ${ }^{44}$

The hypothesis has also been recently proposed that anti-P antibody might have a pathogenic role ${ }^{45}{ }^{46}$ : P0 protein is expressed on the surface of different types of human cells, including endothelial cells, and affinity purified anti-P0 autoantibodies from patients with SLE recognise the surface expressed cognate antigen. ${ }^{47}{ }^{48}$ It is suggested at present that anti-P antibodies may be a type of anti-endothelial cell antibody and cause a direct vascular injury triggered by the antigenic target expressed on endothelial cell surface. ${ }^{48}$ Antigenic specificities of anti-endothelial cell antibodies are considered extremely heterogeneous and, recently, Bordron et al proposed that "some may be pathogenic and may even have the potential to induce the production of antiphospholipid antibodies". ${ }^{49}$

In summary, our results confirm that anti-P antibody is a specific marker of SLE and lupus-like disease and suggest the reliability and diagnostic utility of anti-P antibody screening by immunoblotting in patients with CTD. The autoimmune response against $\mathrm{P}$ proteins is strongly coupled with that against cardiolipin in lupus patients, probably through a common pathogenetic pathway in which the two autoantigens are independently involved. Our data may provide clues about the production and pathogenic role of anti-P antibodies in SLE. 
1 Teh LS, Isenberg DA. Antiribosomal P protein antibodies in systemic lupus erythematosus. A reappraisal Arthritis Rheum 1994;37:307-15.

2 Francoeur AM, Peebles CL, Heckman KJ, Lee JC, Tan EM. Identification of ribosomal protein autoantigens. J Immunol 1985;135:2378-84

3 Sato S, Uchiumi T, Arakawa M, Kominami R. Serological association of lupus autoantibodies to a limited functional domain of $28 \mathrm{~S}$ ribosomal RNA and to the ribosoma proteins bound to the domain. Clin Exp Immunol 1994;98:35-9.

4 Elkon KB, Parnassa AP, Foster CL. Lupus autoantibodies target ribosomal P proteins. J Exp Med 1985;162:459-71.

5 Bonfa E, Parnassa AP, Rhoads DD, Roufa DI, Wool IG Elkon KB. Antiribosomal S10 antibodies in humans and MRL/lpr mice with systemic lupus erythematosus. Arthritis Rheum 1989;32:1252-61.

6 Sato T, Uchiumi T, Ozawa T, Kikuchi M, Nakano M, Kominami $\mathrm{R}$, et al. Autoantibodies against ribosomal proteins found with high frequency in patients with systemic lupus erythematosus with active disease. J systemic lupus erythematosu
Rheumatol 1991;18:1681-4.

7 Elkon KB, Skelly S, Parnassa A, Moller W, Danho W, Weissbach $\mathrm{H}$, et al. Identification and chemical synthesis of a ribosomal protein antigenic determinant in systemic lupus erythematosus. Proc Natl Acad Sci USA 1986;83: 7419-23.

8 Iverson GL. Are antibodies to ribosomal P proteins a clinically useful predictor of neuropsychiatric manifestations in patients with systemic lupus erythematosus? Lupus 1996 5:634-5.

9 Yoshio T, Masuyama JI, Minota S, Kaneko N, Iwamoto M, Okozaki $\mathrm{H}$, et al. A close temporal relationship of liver disease to antiribosomal P0 protein antibodies and central nervous system disease in patients with systemic lupus erythematosus. J Rheumatol 1998;25:681-8.

10 Bonfa E, Elkon KB. Clinical and serologic associations of the antiribosomal $\mathrm{P}$ protein antibody. Arthritis Rheum the antiribosomal

11 Gordon TP, Jovanovich SA, Sykes P, Bradley J, RobertsThompson PJ. Detection of autoantibodies to ribosomal P protein using recombinant autoantigen in a quantitative immunoassay. Rheumatol Int 1990;10:99-102.

12 Bonfa E, Golombek SJ, Kaufman LD, Skelly S, Weissbach $\mathrm{H}$, Brot $\mathrm{N}$, et al. Association between lupus psychosis and anti-ribosomal P protein antibodies. N Engl J Med 1987;317:265-71.

13 van Dam A, Nossent H, de Jong J, Meilof J, ter Borg EJ, Swaak T, et al. Diagnostic value of antibodies against ribosomal phosphoproteins. A cross-sectional and longitudinal study. J Rheumatol 1991;18:1026-34.

14 Tan EM, Cohen AS, Fries JF, Masi AT, McShane DJ, Rothfield NF, et al. The 1982 revised criteria for the classification of systemic lupus erythematosus. Arthritis Rheum 1982;25:1271-7.

15 Subcommittee for scleroderma criteria of the American Rheumatism Association diagnostic and therapeutic criteria committee (1980). Arthritis Rheum 1980;23:581-90.

16 Vitali C, Bombardieri S, Moutsopoulus HM. Preliminary criteria for the classification of Sjogren's syndrome. Arthricriteria for the classification

17 Bohan A, Peter JB. Polymyositis and dermatomyositis. N Engl J Med 1975;13:344-407.

18 Arnett FC, Edworthy SM, Bloch DA, McShane DJ, Fries $\mathrm{JF}$, Cooper NS, et al. The American Rheumatism Association 1987 revised criteria for the classification of rheumatoid arthritis. Arthritis Rheum 1988;31:315-24.

19 Smolen JS, Steiner G. Mixed connective tissue disease: to be or not to be? Arthritis Rheum 1998;41:768-77.

20 Harris EN, Khamashta MA, Hughes GRV. Antiphospholipid antibody syndrome. In: Koopman WJ, McCarty DJ. Arthritis and allied conditions. 12th ed. Philadelphia: Lea and Febiger, 1993.

21 Barr SG, Zonana-Nacach A, Magder LS, Petri M. Patterns of disease activity in systemic lupus erythematosus. Arthritis Rheum 1999;42:2682-8.

22 Ghirardello A, Doria A, Vesco P, Vaccaro E, Bernardi C, Catani C, et al. Blotting patterns of IgG anti-(U1)RNP
antibodies in mixed connective tissue disease. Rheumatol antibodies in mixed

23 McHugh N, James I, Maddison P. Clinical significance of antibodies to a $68 \mathrm{kD}$ U1RNP polypeptide in connective tissue disease. J Rheumatol 1990;17:1320-8.

24 Laemmli UK. Cleavage of structural proteins during the assembly of the head bacteriophage T4. Nature 1970;227: $680-5$.

25 Towbin H, Staehelin T, Gordon J. Electrophoretic transfer of proteins from polyacrylamide gels to nitrocellulose sheets: procedure and some applications. Proc Natl Acad Sci USA 1979;76:4350-4.

26 Olmsted JB. Affinity purification of antibodies from diazotized paper blots of heterogeneous protein samples. J Biol Chem 1981;256:11955-7.

27 Zampieri S, Ghirardello A, Doria A, Tonello M, Bendo R, Rossini $\mathrm{K}$, et al. The use of Tween 20 in immunoblotting ssays for the detection of autoantibodies in connective tissue diseases. J Immunol Methods 2000;239:1-11.

28 Bunn CC, Gharavi AE, Hughes GRV. Antibodies to extractable nuclear antigens in 173 patients with DNA-binding positive SLE: an association between antibodies to ribonucleoprotein and Sm antigens observed by counterimmunoelectrophoresis. J Clin Lab Immunol 1982;8:13-17.

29 Ghirardello A, Doria A, Ruffatti A, Rigoli AM, Vesco P, Calligaro $\mathrm{A}$, et al. Antiphospholipid antibodies (aPL) in systemic lupus erythematosus (SLE). Are they specific tools for the diagnosis of aPL syndrome? Ann Rheum Dis 1994;53:140-2.

30 Harris EN. Antiphospholipid antibodies [annotation]. Br J Haematol 1990;74:1-9.

31 Thiagarajan J, Pengo V, Shapiro S. The use of the diluted Russell viper venom time for the diagnosis of lupus anticoagulants. Blood 1986;4:869-74

32 de Rooij DJ, van de Putte LB, Habets WJ, Verbeek AL, Van Venrooij WJ. The use of immunoblotting to detect antibodies to nuclear and cytoplasmic antigens. Scand J Rheumatol 1988;17:353-64.

33 Nojima Y, Minota S, Yamada A, Takaku F, Aotsuka S, Yokohari R. Correlation of antibodies to ribosomal P protein with psychosis in patients with systemic lupus tein with psychosis in patients with systemic
erythematosus. Ann Rheum Dis 1992;51:1053-5.

34 Magsaam J, Gharavi AE, Parnassa AP, Weissbach H, Brot $\mathrm{N}$, Elkon KB. Quantification of lupus anti-ribosome P antibodies using recombinant $\mathrm{P} 2$ fusion protein and determination of the predicted amino acid sequence of the autoantigen in patients' mononuclear cells. Clin Exp Immunol 1989;76:165-71.

35 Watanabe T, Sato T, Uchiumi T, Arakawa M. Neuropsychiatric manifestations in patients with systemic lupus erythematosus: diagnostic and predictive value of longitudinal examination of anti-ribosomal $\mathrm{P}$ antibody. Lupus 1996;5:178-83.

36 Caponi L, Pegoraro S, Di Bartolo V, Rovero P, Revoltella R, Bombardieri S. Autoantibodies directed against ribosomal P proteins: use of a multiple antigen peptide as the coating
agent in ELISA. J Immunol Methods 1995;179:193-202.

37 Isshi K, Hirohata S. Association of anti-ribosomal P protein antibodies with neuropsychiatric systemic lupus erythematosus. Arthritis Rheum 1996;39:1483-90.

38 Yoshio T, Masuyama JI, Minota S, Iwamoto M, Mimori A, Takeda A, et al. Correlation of serum IgG antibodies to recombinant P0 fusion protein with IgG antibodies to carboxyl-terminal 22 synthetic peptides and carboxylterminal 22 aminoacid-deleted recombinant P0 fusion protein in patients with systemic lupus erythematosus. Arthritis Rheum 1997;40:1364-5.

39 Fujimoto M, Sato S, Takenara K, Nojima Y, Soma Y, Kikuchi K, et al. Detection of antiribosomal P protein antibodies in patients with systemic sclerosis. Br J Rheumatol 1995;34:908-11.

40 Hamasaki K, Mimura T, Kanda H, Morino N, Yasaki Y, Nojima Y. Development of systemic lupus erythematosus in a rheumatoid arthritis patient with anti-ribosomal $\mathrm{P}$ protein antibody. Lupus 1997;6:734-6.

41 Torre JC, Mozo L, Suarez A, Gutierrez C, Ramos E. Antibodies to ribosomal P proteins and hepatic damage in undifferentiated CTD. Ann Rheum Dis 1996;55:562-3.

42 Schneebaum AB, Singleton JD, West SG, Blodgett JK, Allen LG, Cheronis JC, et al. Association of psychiatric manifestations with antibodies to ribosomal $\mathrm{P}$ proteins in systemic lupus erythematosus. Am J Med 1991;90:54-62.

43 Casciola-Rosen LA, Anhalt G, Rosen A. Autoantigens targeted in systemic lupus erythematosus are clustered in two populations of surface structures on apoptotic keratinocytes. J Exp Med 1994;179:1317-30.

44 Casciola-Rosen L, Rosen A, Petri M, Schlissel M. Surface blebs on apoptotic cells are sites of enhanced procoagulant activity: implications for coagulation events and antigenic spread in systemic lupus erythematosus. Proc Natl Acad Sci USA 1996;93:1624-9.

45 Koscec M, Koren E, Wolfson-Reichlin M, Fugate RD, Trieu E, Targoff IN, et al. Autoantibodies to ribosomal $P$ proteins penetrate into live hepatocytes and cause cellular dysfunction in culture. J Immunol 1997;159:2033-41.

46 Winfield JB. Are anti-ribosomal P protein antibodies a type of anti-lymphocyte antibody? Clin Exp Immunol 1997; 109:1-3.

47 Koren E, Wolfson-Reichlin M, Koscec M, Fugate RD, Reichlin $M$. Autoantibodies to the ribosomal P proteins react with a plasma membrane-related target on human cells. J Clin Invest 1992;89:1236-41.

48 Yoshio T, Masuyama JI, Kano S. Antiribosomal P0 protein endothelial cells. J Rheumatol 1996;23:1311-12.

49 Bordron A, Dueymes M, Levy Y, Jamin C, Ziporen L, Piette JC, et al. Anti-endothelial cell antibody binding makes negatively charged phospholipids accessible to antiphospholipid antibodies. Arthritis Rheum 1998;41:1738-47. 